\title{
Differential production and secretion of potentially toxigenic extracellular proteins from hypervirulent Aeromonas hydrophila under biofilm and planktonic culture
}

\author{
Priscilla C. Barger ${ }^{1,2^{*}}$ (D) Mark R. Liles ${ }^{2}$, Benjamin H. Beck ${ }^{3}$ and Joseph C. Newton ${ }^{1 *}$
}

\begin{abstract}
Background: Hypervirulent Aeromonas hydrophila (vAh) is an emerging pathogen in freshwater aquaculture that results in the loss of over 3 million pounds of marketable channel catfish, Ictalurus punctatus, and channel catfish hybrids (I. punctatus, 9 x blue catfish, I. furcatus, ô) each year from freshwater catfish production systems in Alabama, U.S.A. vAh isolates are clonal in nature and are genetically unique from, and significantly more virulent than, traditional A. hydrophila isolates from fish. Even with the increased virulence, natural infections cannot be reproduced in aquaria challenges making it difficult to determine modes of infection and the pathophysiology behind the devastating mortalities that are commonly observed. Despite the intimate connection between environmental adaptation and plastic response, the role of environmental adaption on vAh pathogenicity and virulence has not been previously explored. In this study, secreted proteins of vAh cultured as free-living planktonic cells and within a biofilm were compared to elucidate the role of biofilm growth on virulence.

Results: Functional proteolytic assays found significantly increased degradative activity in biofilm secretomes; in contrast, planktonic secretomes had significantly increased hemolytic activity, suggesting higher toxigenic potential. Intramuscular injection challenges in a channel catfish model showed that in vitro degradative activity translated into in vivo tissue destruction. Identification of secreted proteins by HPLC-MS/MS revealed the presence of many putative virulence proteins under both growth conditions. Biofilm grown vAh produced higher levels of proteolytic enzymes and adhesins, whereas planktonically grown cells secreted higher levels of toxins, porins, and fimbrial proteins.

*Correspondence: bargepc@auburn.edu; newtojc@auburn.edu

'Department of Pathobiology, College of Veterinary Medicine, Auburn University, Auburn, AL, USA

Full list of author information is available at the end of the article

(c) The Author(s). 2020, corrected publication 2021. Open Access This article is licensed under a Creative Commons Attribution 4.0 International License, which permits use, sharing, adaptation, distribution and reproduction in any medium or format, as long as you give appropriate credit to the original author(s) and the source, provide a link to the Creative Commons licence, and indicate if changes were made. The images or other third party material in this article are included in the article's Creative Commons licence, unless indicated otherwise in a credit line to the material. If material is not included in the article's Creative Commons licence and your intended use is not permitted by statutory regulation or exceeds the permitted use, you will need to obtain permission directly from the copyright holder. To view a copy of this licence, visit http://creativecommons.org/ licenses/by/4.0/. The Creative Commons Public Domain Dedication waiver (http://creativecommons.org/publicdomain/zero/1. 0/) applies to the data made available in this article, unless otherwise stated in a credit line to the data. 


\begin{abstract}
(Continued from previous page)
Conclusions: This study is the first comparison of the secreted proteomes of vAh when grown in two distinct ecological niches. These data on the adaptive physiological response of vAh based on growth condition increase our understanding of how environmental niche partitioning could affect vAh pathogenicity and virulence. Increased secretion of colonization factors and degradative enzymes during biofilm growth and residency may increase bacterial attachment and host invasiveness, while increased secretion of hemolysins, porins, and other potential toxins under planktonic growth (or after host invasion) could result in increased host mortality. The results of this research underscore the need to use culture methods that more closely mimic natural ecological habitat growth to improve our understanding of vAh pathogenesis.
\end{abstract}

Keywords: Hypervirulent Aeromonas hydrophila, vAh, Extracellular protein secretion, Secretome, Biofilm, Ecological niche adaptation, Pathogenicity, Virulence

\section{Background}

Aeromonas hydrophila is a wide-spread and diverse species of Gram-negative bacterium ubiquitous in freshwater aquatic ecosystems. As a rapidly growing and metabolically diverse generalist [1-5], A. hydrophila is capable of exploiting a variety of ecological habitats and a broad range of hosts. A. hydrophila has been isolated from almost every freshwater aquatic environment and from diseased mammals, reptiles, amphibians, insects, and fish [1, 6-8]. A. hydrophila has been found in association with processed poultry, meats, fish, and even bottled water. It is capable of withstanding chlorination and is resistant to multiple antibiotics [1,9].

In aquaculture, $A$. hydrophila is an important cause of disease in most freshwater production systems. Historically, A. hydrophila has been an important secondary pathogen in catfish production systems, commonly responsible for cutaneous ulceration and muscle necrosis. Occasionally following fish stress (low oxygen, poor water quality, etc.) the bacterium can cause a septicemia (motile aeromonad septicemia [MAS]), resulting in high mortalities [10-14]. In 2009, a new, highly virulent strain of $A$. hydrophila was isolated from a diseased channel catfish, Ictalurus punctatus, within a production pond in West Alabama. This strain, referred to as hypervirulent Aeromonas hydrophila, or vAh, was responsible for outbreaks of peracute motile aeromonad septicemia of epidemic proportions [11, 15-19]. vAh apparently acts as a primary pathogen, and may not be preceded by immune insult [11]. To date, vAh has been responsible for the loss of 30 million pounds of marketable channel catfish from production farms in West Alabama. In 2017, A. hydrophila infections were responsible for the loss of 3.4 million pounds of farm-raised catfish in Alabama alone, more than twice as much as the second leading cause of loss, Flavobacterium columnare. vAh has been the primary or secondary cause of catfish loss in Alabama since the primary outbreak in 2009 (Hemstreet, AL Fish Farming Center).
While much current research is focused on MAS disease prevention, there are many important unanswered areas of research to understanding the mechanisms of vAh pathogenesis, bacterial-host interactions, and bacterial adaptive responses under different environmental conditions. A. hydrophila are known to secrete a multitude of degradative and cytotoxic extracellular proteins which are widely accepted as virulence determinants [20-22], and which likely contribute to the environmental adaptability and broad species host range.

While vAh has established itself as a primary pathogen in natural settings [11], laboratory-cultured vAh appears to mimic its opportunistic relatives during immersion challenges. Planktonically-cultured vAh is extremely virulent, causing death in a matter of hours in intraperitoneal injection challenges. However, models meant to mimic more natural infections including submersion and gavage have been unreliable, even when challenged with artificially high colony forming units (CFUs) of the bacterium [2, 23]. Current studies of vAh pathogenesis and virulence are performed almost exclusively with planktonically-cultured bacteria despite the fact that most free-living generalist bacteria in aquatic systems reside primarily within biofilm [24-29]. One study using only planktonically-cultured vAh reported the presence of 228 extracellular proteins (ECPs) in the supernatant of vAh broth cultures, at least 23 of which were putative virulence factors [18], and a recent study comparing the secretomes of wild-type vAh with that of a group four capsule (gfc) - deficient vAh mutant reported the presence of multiple degradative and hemolytic proteins under planktonic culture [30]. A comparative proteomics study by Wang et al. [31] found differential expression of 33 proteins, many of which were involved in proteolysis, in response to iron starvation, underscoring the role of secreted proteins in environmental adaptation of vAh. Though niche adaptation clearly plays an important role in protein secretion, no studies have evaluated the secretome of biofilm grown vAh. A recent 
study by Cai et al. (2018) found no vAh present in the water column through the survey period, (July-October), while vAh resident in biofilm and pond sediment was detected at an increasing rate in the same sampling period, suggesting that biofilms serve as a stable reservoir for vAh survival when planktonic conditions are less favorable. Biofilm-associated bacteria generally have increased adhesive properties [24, 25, 32-34] and may have increased production of proteolytic enzymes, both of which could increase virulence [12, 35-37]. Redfield (2002) suggested that extracellular proteases are expressed when diffusion and/or mixing is reduced. vAh residing within a biofilm may have an advantage in attaching to and invading fish tissues due to increased secretion of proteolytic enzymes and adhesins. Given the data supporting the presence of vAh within pond biofilms, it is important to identify virulence factors secreted during biofilm residence that could impact host attachment and invasion. In this study, we compared the secreted protein profiles (secretomes) of biofilm- or planktonically cultured vAh strain ML09-119 to determine if niche occupation could influence vAh pathogenicity in natural environments.

\section{Results}

Biofilm grown vAh express higher protease activity but less hemolytic activity than planktonic cultures

Protease activity in biofilm samples was observed to be more than 2 times higher than in planktonic samples, and 1.2 times higher than the trypsin positive control $(p<0.05$; Fig. 1$)$. Similarly, elastase activity was significantly higher for biofilm grown vAh, which expressed 2.7 greater elastase activity than observed for planktonically grown cultures $(p<0.05$; Fig. 2$)$. In contrast, hemolytic activity was greatly increased in planktonic cultures, with more than 6 times higher hemolytic activity compared to biofilm grown vAh $(p<0.05$; Fig. 3$)$.

\section{Severe fish tissue necrosis was induced by the secretome of biofilm-grown vAh}

To determine if the increased proteinase and elastase activities observed from vAh when grown as an in vitro biofilm would result in tissue damage indicative of MAS disease, $10 \mu \mathrm{g}$ of secreted proteins from each growth condition was injected intra-muscularly into channel catfish. Two hours post-injection, loss of dermal pigment was noted at the injection site in biofilm-injected fish, but no changes were observed for the injected planktonic secretome. After $24 \mathrm{~h}$, substantial tissue necrosis was observed grossly in all biofilm-injected fish (Fig. 4). Fish injected with planktonic-associated ECPs developed no gross lesions even after 7 days. No control fish developed any gross lesion at the injection site after 7 days.

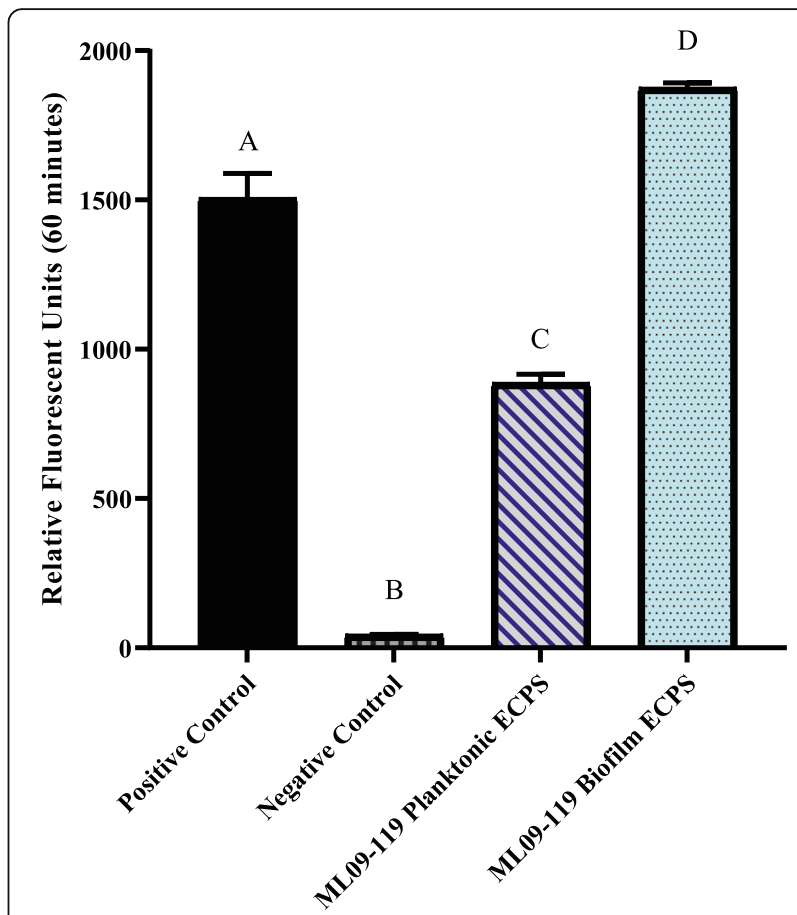

Fig. 1 General proteolytic potential of vAh extracellular proteins (ECPs) secreted under biofilm and planktonic growth. The general proteolytic potential of biofilm and planktonic secretomes was measure using HiLyteFluor 488-labeled casein as a substrate. Secreted protein from each condition was incubated at $30^{\circ} \mathrm{C}$ with labeled casein and fluorescent intensity was measured at $\mathrm{Ex} / \mathrm{Em}=$ $490 \mathrm{~nm} / 520 \mathrm{~nm}$ every five minutes for one hour. Data were plotted as relative fluorescence units versus time for each sample. Trypsin served as a positive control, and sterile, deionized water served as a negative control. Three individual experiments were performed, and all samples were performed in triplicate. Statistical analysis consisted of one-way ANOVA followed by Tukey's multiple comparisons posttest with significance set at $p<0.05$

Histopathology was performed on skin and subcutaneous tissues collected from injection sites of channel catfish. Biofilm-injected fish tissue was edematous, hemorrhagic, and there was extensive tissue necrosis at the site of injection (Fig. 4). Despite substantial tissue damage, few inflammatory cells were present. In contrast, fish injected with planktonic ECPs were identical to the control fish, with no perceptible damage to skin, subcutaneous adipose tissue, or muscle.

\section{Biofilm and planktonically grown vAh have distinct secretomes}

The differences in enzyme activities and tissue damage observed for biofilm versus planktonically-cultured vAh supported the hypothesis that niche occupancy has a significant influence on vAh exoprotein expression. To further test this hypothesis, a secretome analysis was performed to identify differentially secreted proteins present under the two culture conditions. A total of 272 


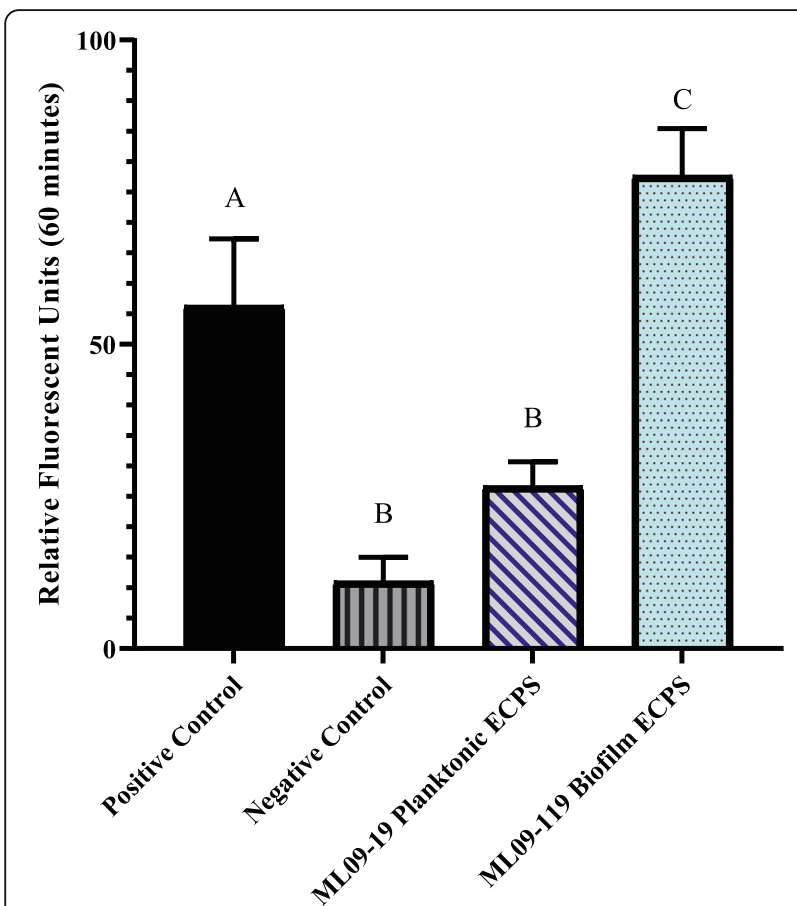

Fig. 2 Elastase-specific degradative potential of vAh extracellular proteins (ECPs) secreted under biofilm and planktonic growth. The elastase activity of biofilm and planktonic secretomes was measure using 5-FAM/QXL ${ }^{\text {TM }}$ 520-labeled elastin as a substrate. Secreted protein from each condition was incubated at $30^{\circ} \mathrm{C}$ with labeled elastin and fluorescent intensity was measured at Ex/Em $=490 \mathrm{~nm} /$ $520 \mathrm{~nm}$ every five minutes for one hour. Elastase served as a positive control and sterile, deionized water served as a negative control. Data were plotted as relative fluorescence units versus time for each sample. Three individual experiments were performed, and all samples were performed in triplicate. Statistical analysis consisted of one-way ANOVA followed by Tukey's multiple comparisons post-test with significance set at $p<0.05$

proteins were identified in the secretomes of biofilm and planktonically-cultured vAh. Eighty-two proteins were identified that were present in both secretomes, while 98 were identified only in biofilm secretomes and 92 were unique to planktonic secretomes. ROTS and T-test analyses identified 53 proteins that significantly (FDR $<0.05$, $p=0.01$ ) varied in abundance. The protein abundance ratios of 52 ROTS-identified proteins were above the significant fold change threshold of $\geq 1.5$ (Table 1). Thirty-five proteins were significantly increased in the biofilm secretomes, 20 of which were uniquely present in samples from biofilm grown vAh; for planktonic secretomes, 15 proteins were significantly increased in their abundance relative to biofilm samples, and these included nine proteins that were only observed from planktonic cultures. Of the proteins that varied significantly in their abundance, at least 15 from planktonic secretomes and 30 from biofilm secretomes have been indicated in virulence (Table 1, in bold font). However,

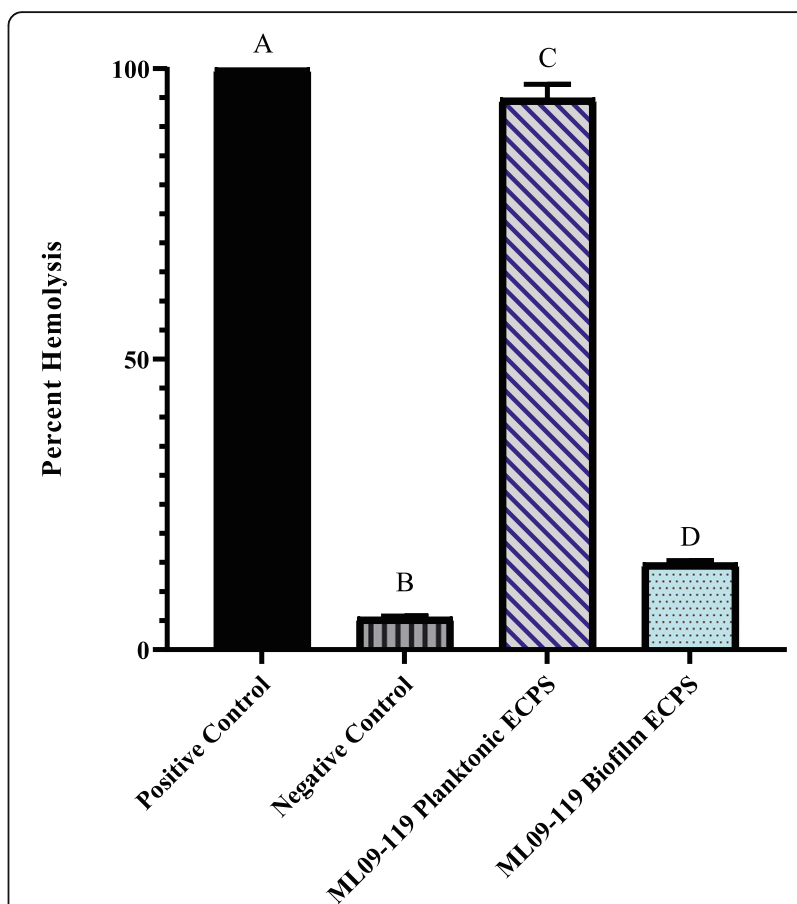

Fig. 3 Hemolytic potential of vAh extracellular proteins secreted under biofilm and planktonic growth. The hemolytic ability of vAh secreted proteins was measured using channel catfish erythrocytes as the substrate. $2.5 \mu \mathrm{g}$ secreted proteins from each culture condition was incubated with $25 \mu$ catfish blood diluted 1:10 in sterile PBS. at $30^{\circ} \mathrm{C}$ with shaking. Sterile, deionized water served as positive control and sterile PBS served as a negative control. Lysis was calculated by measuring sample absorbance at $415 \mathrm{~nm}$, and reported as percent positive control. All samples were assayed in triplicate. Statistical analysis consisted of one-way ANOVA followed by Tukey's multiple comparisons post-test with significance set at $p<0.05$

not all secreted putative virulence proteins were differentially secreted, with many putative virulence factors identified in secretomes under both conditions.

Functional group comparisons based on gene ontology (Table 1, Fig. 5) revealed extensive secretion of degradative enzymes and toxins in both biofilm and planktonic secretomes, with degradative enzymes, such as elastase, metalloprotease, chitinase, and endochitinase, dominating biofilm secretomes and cytotoxic and cytotonic toxins, such as ahh1-type hemolysin and extracellular lipase enriched in planktonic secretomes. In both planktonic and biofilm secretomes, degradative enzymes and toxins made up the majority of significant proteins, representing $79.8 \%$ of planktonic proteins and $55.7 \%$ of biofilm proteins. Proteins involved in transport (16.5\%), carbohydrate metabolism (8.5\%), and pilus and flagellin (3.6\%) contributed significantly to the biofilm secretome, while pilus and flagellin proteins (5.8\%), outer membrane proteins $(4.0 \%)$, and proteins involved in 


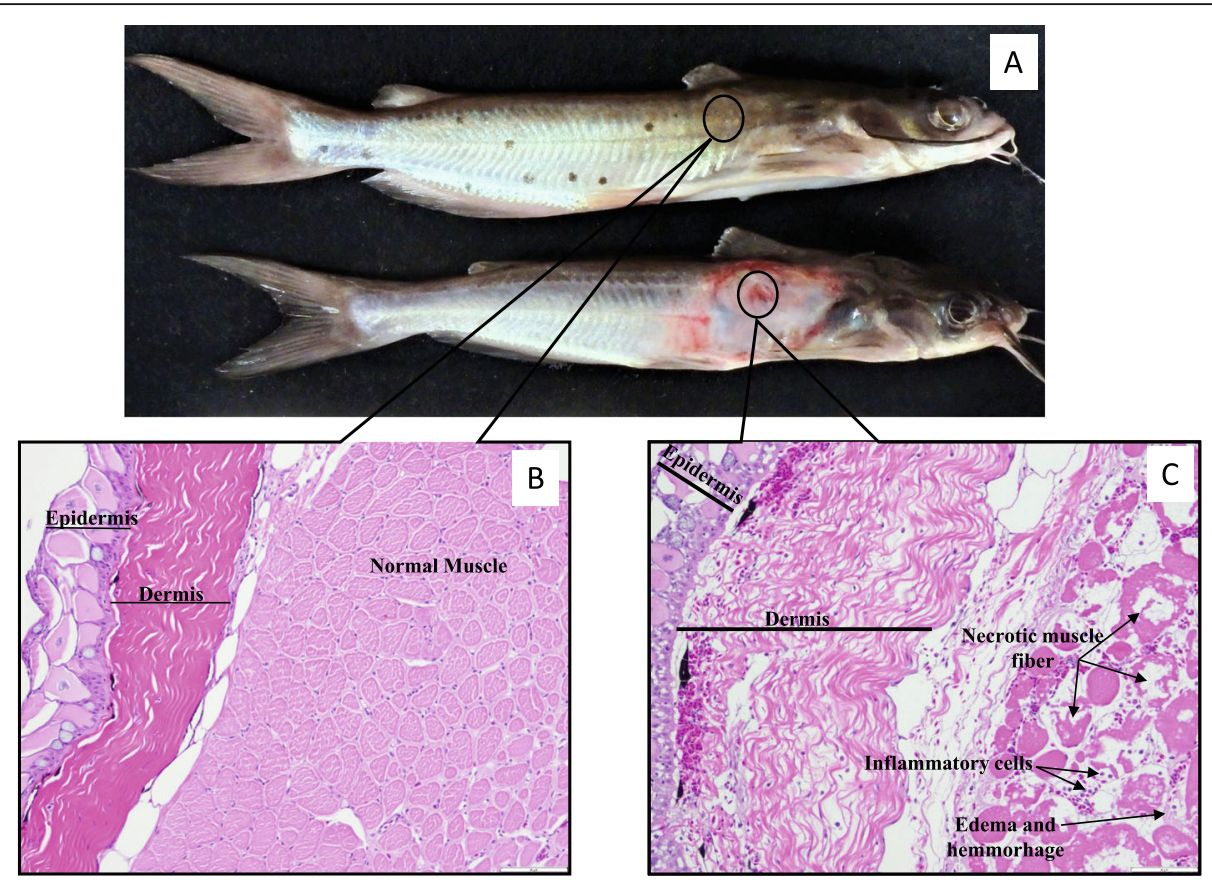

Fig. 4 Gross lesions and histopathology of channel catfish muscle following intramuscular injection with vAh secreted proteins. (A) Channel catfish injected with Control (top) and biofilm-cultured vAh secreted proteins (bottom) $24 \mathrm{~h}$ post-injection, with black circle denoting injection site. Histologic sections prepared from paraffin-embedded tissues were stained with hematotoxylin and eosin. (B) Control (200X) - No perceptible damage to skin, subcutaneous adipose tissue, or muscle. Fish injected with planktonic ECPs were indistinguishable from controls. (C) Biofilminjected fish tissue (200X) $24 \mathrm{~h}$ post-injection. Tissue was edematous, hemorrhagic, and necrotic at the injection site. Despite substantial tissue damage, few inflammatory cells were present

transcriptional regulation and electron transport (3.5\%) were other significant contributors to planktonic secretomes (Fig. 5). Of particular interest were the presence of polar flagellar proteins (AHML_09345 and _09350) present in higher quantities in the biofilm secretome and type I pili proteins (AHML_2665 and_2690) that were present in planktonic secretomes, but absent from biofilm secretomes. Polar flagella, typically considered motility flagella, are important in adhesion and invasion in A. hydrophila that lack lateral flagella, such as vAh [38], while type I pili are thought to contribute to host colonization, but not host invasion [39].

\section{Discussion}

While vAh are significantly more virulent that traditional A. hydrophila when challenged by intraperitoneal injection [15], Zhang et al. [40] reported consistent vMAS mortality was attainable in channel catfish immersion trials only following scarification and challenge with $2 \times 10^{7} \mathrm{CFU} / \mathrm{ml}$ of planktonically-cultured vAh. This suggests that some environmental stimuli are not present in artificial broth culture, which, in pond systems, could be responsible for inducing bacterial virulence and resulting in large scale MAS epidemic outbreaks. Since most environmental bacteria spend much of their time in biofilm, either attached to a substrate or floating as bacterial flocs $[24,26,27,29,41]$, biofilmassociated vAh may produce proteins that increase invasiveness and allow initial colonization in vivo [42]. The ability to form a biofilm is commonly considered a virulence factor, particularly in human disease conditions [43]. Likewise, for A. hydrophila biofilm formation and residency may induce global changes in gene expression resulting in increased production and secretion of degradative enzymes and other factors that increase pathogenicity or invasiveness. Aeromonas spp. produce extracellular enzymes that facilitate nutrient acquisition in aquatic environments and produce adhesins that aid in the attachment and colonization of benthic surfaces [5]. In aquatic environments, these enzymes provide nutrients by degrading the organic compounds including suspended detritus and benthic substrates. These enzymes may also be important in the pathophysiology of disease by enabling degradation of animal tissues [5, 24, 44].

Previous research reported the presence multiple potentially toxigenic extracellular proteins in the supernatant of planktonically-cultured vAh $[18,30]$. Because many opportunistic bacteria like $\mathrm{vAh}$ reside largely in biofilms and not as sustained planktonic populations [45], it was important to evaluate the influence of biofilm growth on vAh exoprotein expression. This study 
Table 1 Differentially secreted proteins of planktonic and biofilm-cultured ML09-119

\begin{tabular}{|c|c|c|c|c|c|c|}
\hline Secreted Protein & Locus Tag & $\begin{array}{l}\text { ROTS- } \\
\text { Statistic }\end{array}$ & $\begin{array}{l}p \\
\text { value }\end{array}$ & FDR & $\begin{array}{l}\text { Protein Abundance } \\
\text { Fold Change }\end{array}$ & $\begin{array}{l}\text { Significant Experimental } \\
\text { Group }\end{array}$ \\
\hline \multicolumn{7}{|l|}{ Transcription regulation/ e- Transport } \\
\hline DNA gyrase inhibitor & $\begin{array}{l}\text { AHML_- } \\
21105\end{array}$ & 2.2 & 0.01 & 0 & $16^{\mathrm{a}}$ & $\mathrm{BIO}$ \\
\hline Ribonuclease activity regulator & $\begin{array}{l}\text { AHML_- } \\
16315\end{array}$ & 1.55 & 0.02 & 0.02 & 2.5 & $\mathrm{BIO}$ \\
\hline $\begin{array}{l}\text { FKBP-type peptidyl-prolyl cis-trans } \\
\text { isomerase }\end{array}$ & $\begin{array}{l}\text { AHML_} \\
05355\end{array}$ & -2.10 & 0.01 & 0 & $22^{\mathrm{a}}$ & TSB \\
\hline Cytochrome d ubiquinol oxidase & $\begin{array}{l}\mathrm{AHML}_{-} \\
19200\end{array}$ & -1.71 & 0.02 & 0.02 & 16 & TSB \\
\hline \multicolumn{7}{|l|}{ Free Radical Scavenging } \\
\hline Superoxide dismutase & $\begin{array}{l}\text { AHML_- } \\
07590\end{array}$ & 2.95 & 0.01 & 0 & 6 & $\mathrm{BIO}$ \\
\hline Glyoxalase/dioxygenase protein & $\begin{array}{l}\text { AHML_- } \\
09045\end{array}$ & 1.89 & 0.01 & 0.03 & $13^{\mathrm{a}}$ & $\mathrm{BIO}$ \\
\hline \multicolumn{7}{|l|}{ Amino Acid/Cofactor Metabolism } \\
\hline Redox protein (hypothetical) & $\begin{array}{l}\mathrm{AHML}_{-} \\
05250\end{array}$ & 2.33 & 0.01 & 0 & $19^{a}$ & $\mathrm{BIO}$ \\
\hline Diaminopimelate epimerase & $\begin{array}{l}\text { AHML_- } \\
02440\end{array}$ & 1.82 & 0.02 & 0.03 & $9^{a}$ & $\mathrm{BIO}$ \\
\hline Ornithine carbamoyltransferase & $\begin{array}{l}\text { AHML_- } \\
21555\end{array}$ & -1.35 & 0.03 & 0.05 & 3.5 & TSB \\
\hline Riboflavin-biosynthesis protein & $\begin{array}{l}\text { AHML_- } \\
17795\end{array}$ & 1.4 & 0.02 & 0.05 & 2.4 & $\mathrm{BIO}$ \\
\hline Urocanate hydratase & $\begin{array}{l}\text { AHML_- } \\
01870\end{array}$ & 3.71 & 0.00 & 0 & 8 & $\mathrm{BIO}$ \\
\hline Dihydrodipicolinate synthase & $\begin{array}{l}\mathrm{AHML}_{-} \\
04540\end{array}$ & 2.35 & 0.01 & 0 & $22^{\mathrm{a}}$ & $\mathrm{BIO}$ \\
\hline Succinylarginine dihydrolase & $\begin{array}{l}\text { AHML_- } \\
16715\end{array}$ & 5.49 & 0.00 & 0 & $66^{\mathrm{a}}$ & $\mathrm{BIO}$ \\
\hline \multicolumn{7}{|l|}{ Carbohydrate Metabolism } \\
\hline Maltose operon periplasmic protein & $\begin{array}{l}\text { AHML_- } \\
06220\end{array}$ & 2.57 & 0.01 & 0 & $15^{\mathrm{a}}$ & $\mathrm{BIO}$ \\
\hline Phosphoglyceromutase & $\begin{array}{l}\text { AHML_- } \\
01445\end{array}$ & 1.94 & 0.01 & 0 & $13^{\mathrm{a}}$ & $\mathrm{BIO}$ \\
\hline Transaldolase B & $\begin{array}{l}\text { AHML_- } \\
16890\end{array}$ & 8.08 & 0.00 & 0 & $89^{a}$ & $\mathrm{BIO}$ \\
\hline Pullulanase & $\begin{array}{l}\text { AHML_- } \\
04415\end{array}$ & 3.62 & 0.00 & 0 & 10 & $\mathrm{BIO}$ \\
\hline Ribose-5-phosphate isomerase A & $\begin{array}{l}\text { AHML_- } \\
14480\end{array}$ & 2.92 & 0.01 & 0 & 3 & $\mathrm{BIO}$ \\
\hline Beta-glucosidase & $\begin{array}{l}\text { AHML_- } \\
14270\end{array}$ & -1.68 & 0.02 & 0.0 & 14 & TSB \\
\hline \multicolumn{7}{|l|}{ Outer Membrane Proteins } \\
\hline Outer membrane protein $A$ & $\begin{array}{l}\text { AHML_- } \\
21905\end{array}$ & -1.99 & 0.01 & 0 & 4 & TSB \\
\hline Outer membrane protein $\mathrm{A}$ & $\begin{array}{l}\text { AHML_- } \\
20145\end{array}$ & 1.46 & 0.02 & 0.04 & $13^{\mathrm{a}}$ & $\mathrm{BIO}$ \\
\hline Outer membrane lipoprotein & $\begin{array}{l}\text { AHML_- } \\
00700\end{array}$ & -1.58 & 0.02 & 0.02 & $13^{\mathrm{a}}$ & TSB \\
\hline \multicolumn{7}{|l|}{ Degradative Enzymes and Toxins } \\
\hline Hemolysin (Aerolysin-type) & $\begin{array}{l}\text { AHML__ } \\
02265\end{array}$ & -2.37 & 0.01 & 0 & 3 & TSB \\
\hline
\end{tabular}


Table 1 Differentially secreted proteins of planktonic and biofilm-cultured ML09-119 (Continued)

\begin{tabular}{|c|c|c|c|c|c|c|}
\hline Secreted Protein & Locus Tag & $\begin{array}{l}\text { ROTS- } \\
\text { Statistic }\end{array}$ & $\begin{array}{l}p \\
\text { value }\end{array}$ & FDR & $\begin{array}{l}\text { Protein Abundance } \\
\text { Fold Change }\end{array}$ & $\begin{array}{l}\text { Significant Experimental } \\
\text { Group }\end{array}$ \\
\hline Hemolysin (ahh1-type) & $\begin{array}{l}\text { AHML_ } \\
08400\end{array}$ & -2.69 & 0.01 & 0 & 4 & TSB \\
\hline Elastase & $\begin{array}{l}\text { AHML } \\
04340\end{array}$ & 4.68 & 0.00 & 0 & 5 & $\mathrm{BIO}$ \\
\hline Chitinase & $\begin{array}{l}\text { AHML_- } \\
05225\end{array}$ & 4.07 & 0.00 & 0 & 3 & $\mathrm{BIO}$ \\
\hline Metalloprotease & $\begin{array}{l}\text { AHML_- } \\
05230\end{array}$ & 2.73 & 0.01 & 0 & 3 & $\mathrm{BIO}$ \\
\hline Basic endochitinase & $\begin{array}{l}\text { AHML_- } \\
05235\end{array}$ & 3.15 & 0.01 & 0 & 3 & $\mathrm{BIO}$ \\
\hline Zn-dependent carboxypeptidase & $\begin{array}{l}\mathrm{AHML}_{-} \\
05535\end{array}$ & 2.15 & 0.01 & 0 & $13^{\mathrm{a}}$ & $\mathrm{BIO}$ \\
\hline Outer membrane porin protein & $\begin{array}{l}\text { AHML } \\
04355\end{array}$ & 2.91 & 0.01 & 0 & $15^{\mathrm{a}}$ & $\mathrm{BIO}$ \\
\hline Extracellular lipase & $\begin{array}{l}\text { AHML_- } \\
00550\end{array}$ & -4.16 & 0.01 & 0 & 3 & TSB \\
\hline Chitin-binding domain 3 & $\begin{array}{l}\text { AHML_- } \\
11110\end{array}$ & -1.50 & 0.02 & 0.02 & 12 & TSB \\
\hline $\begin{array}{l}\text { Zn-dependent protease with chaperone } \\
\text { function }\end{array}$ & $\begin{array}{l}\text { AHML_- } \\
06635\end{array}$ & 1.51 & 0.02 & 0.02 & $11^{a}$ & $\mathrm{BIO}$ \\
\hline Phosphoglyceromutase & $\begin{array}{l}\text { AHML_- } \\
01445\end{array}$ & 1.94 & 0.01 & 0 & $13^{\mathrm{a}}$ & $\mathrm{BIO}$ \\
\hline Phospholipid-cholesterol acyltransferase & $\begin{array}{l}\text { AHML_- } \\
20135\end{array}$ & -1.55 & 0.02 & 0.02 & $14^{\mathrm{a}}$ & TSB \\
\hline Aminopeptidase & $\begin{array}{l}\text { AHML_- } \\
18480\end{array}$ & -1.55 & 0.02 & 0.02 & 2 & TSB \\
\hline Chitin binding protein & $\begin{array}{l}\text { AHML_- } \\
03125\end{array}$ & 1.59 & 0.02 & 0.02 & 1.6 & $\mathrm{BIO}$ \\
\hline Proline iminopeptidase & $\begin{array}{l}\text { AHML } \\
18440\end{array}$ & 1.88 & 0.01 & 0.03 & $14^{a}$ & $\mathrm{BIO}$ \\
\hline Serine Protease & $\begin{array}{l}\text { AHML_- } \\
14260\end{array}$ & -1.91 & 0.01 & 0.03 & 19 & TSB \\
\hline Periplasmic carboxy-terminal protease & $\begin{array}{l}\text { AHML } \\
11480\end{array}$ & 2.28 & 0.01 & 0 & $14^{\mathrm{a}}$ & $\mathrm{BIO}$ \\
\hline Collagenase family & $\begin{array}{l}\text { AHML_- } \\
02655\end{array}$ & -1.90 & 0.01 & 0.03 & 2.5 & TSB \\
\hline Extracellular alkaline serine protease & $\begin{array}{l}\text { AHML_- } \\
18455\end{array}$ & -2.22 & 0.01 & 0 & $25^{\mathrm{a}}$ & TSB \\
\hline Small protease & $\begin{array}{l}\text { AHML_- } \\
08855\end{array}$ & 1.37 & 0.03 & 0.05 & $8^{a}$ & $\mathrm{BIO}$ \\
\hline \multicolumn{7}{|l|}{ Pilus and Flagellin Proteins } \\
\hline Flagellin & $\begin{array}{l}\text { AHML_- } \\
09350\end{array}$ & 5.42 & 0.00 & 0 & $43^{a}$ & $\mathrm{BIO}$ \\
\hline Flagellin-like protein & $\begin{array}{l}\text { AHML_- } \\
09345\end{array}$ & 2.05 & 0.01 & 0 & 2.6 & $\mathrm{BIO}$ \\
\hline Type I pilus assembly protein FimF & $\begin{array}{l}\text { AHML_- } \\
02690\end{array}$ & -2.29 & 0.01 & 0 & $26^{a}$ & TSB \\
\hline Fimbrial Proteain & $\begin{array}{l}\text { AHML_- } \\
02665\end{array}$ & -2.61 & 0.01 & 0 & $36^{a}$ & TSB \\
\hline \multicolumn{7}{|l|}{ Transport Proteins } \\
\hline$A B C$-type sugar transport & $\begin{array}{l}\text { AHML_- } \\
20895\end{array}$ & 1.77 & 0.02 & 0.02 & $14^{\mathrm{a}}$ & $\mathrm{BIO}$ \\
\hline
\end{tabular}


Table 1 Differentially secreted proteins of planktonic and biofilm-cultured ML09-119 (Continued)

\begin{tabular}{|c|c|c|c|c|c|c|}
\hline Secreted Protein & Locus Tag & $\begin{array}{l}\text { ROTS- } \\
\text { Statistic }\end{array}$ & $\begin{array}{l}p \\
\text { value }\end{array}$ & FDR & $\begin{array}{l}\text { Protein Abundance } \\
\text { Fold Change }\end{array}$ & $\begin{array}{l}\text { Significant Experimental } \\
\text { Group }\end{array}$ \\
\hline TonB-dependent copper receptor & $\begin{array}{l}\text { AHML_- } \\
02545\end{array}$ & 1.79 & 0.02 & 0.02 & 9 & $\mathrm{BIO}$ \\
\hline Peptide $A B C$ transporter & $\begin{array}{l}\text { AHML_ } \\
17755\end{array}$ & 3.2 & 0.00 & 0 & $98^{\mathrm{a}}$ & $\mathrm{BIO}$ \\
\hline Arginine $A B C$ transporter & $\begin{array}{l}\text { AHML_} \\
03370\end{array}$ & 4.58 & 0.00 & 0 & 7 & $\mathrm{BlO}$ \\
\hline Oligopeptide $A B C$ transporter & $\begin{array}{l}\text { AHML_} \\
13875\end{array}$ & 6.05 & 0.00 & 0 & $93^{\mathrm{a}}$ & $\mathrm{BlO}$ \\
\hline Leucine binding protein ( $A B C$ transport) & $\begin{array}{l}\text { AHML__ } \\
00595\end{array}$ & 3.74 & 0.00 & 0 & 18 & $\mathrm{BIO}$ \\
\hline
\end{tabular}

Differentially secreted proteins of vAh ML09-119 cultured planktonically (TSB) and within a biofilm (BIO). Proteins are grouped based on their major biological process, determined by gene ontology. Protein abundance fold change marked with ${ }^{\text {a }}$ denotes protein identified in only one condition and is reported as the average Quantitative Protein Value. Proteins and locus tags in Bold indicate putative virulence proteins. FDR $=$ False Discovery rate

found that degradative activities were significantly increased in the supernatant of biofilm-associated vAh (Figs. 1 and 2). Furthermore, when biofilm-grown vAh ECPs were injected into the muscle of channel catfish, significant necrosis and cytolysis occurred within $24 \mathrm{~h}$, while secreted proteins of planktonically-cultured vAh failed to produce necrotic lesions after seven days.

A secretome analysis was conducted to examine in more detail how biofilm growth influenced vAh exoprotein expression, which revealed significant differences in the secretomes of the two cultures, both in complexity and quantity. The biofilm secretome contained 248 proteins, including 183 unique proteins, while planktonic secretomes contained 183 total proteins, including 101 unique proteins. Of the 82 proteins secreted under both culture conditions, at least 36 had previously been identified as putative virulence factors [18, 21, 46]. Under both growth conditions, vAh secreted an

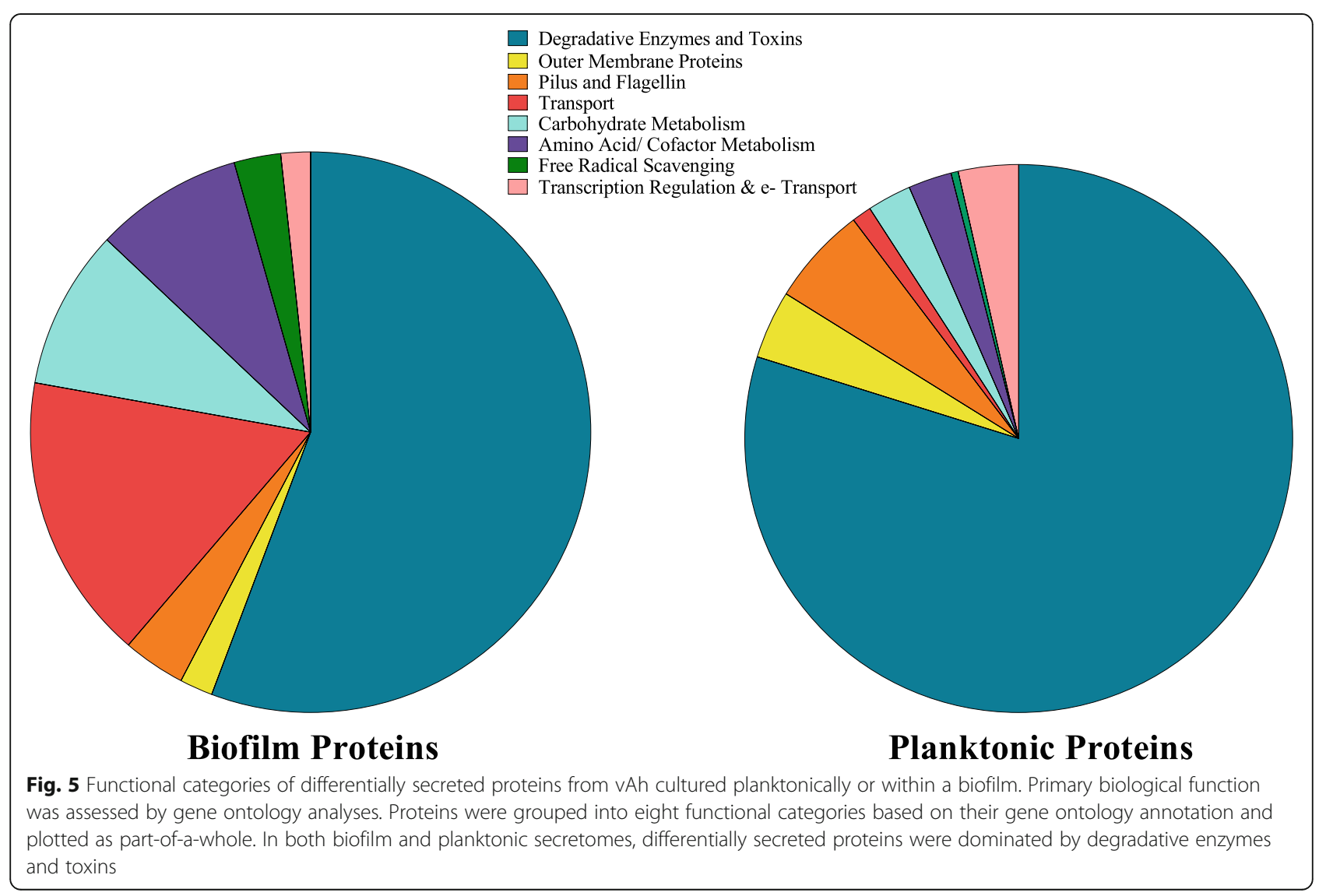


abundance of potential virulence proteins, the majority of which were not statistically significant in differential secretion analyses. However, secretomes of vAh cultured in biofilm were significantly more varied and, in general, relative protein abundance was increased.

Assays to measure general and specific proteolytic potential of the secreted proteins revealed significant increases in both caseinolytic and elastinolytic activity in biofilm secretomes when compared to planktonic ECPs (Figs. 1 and 2). A significant difference in proteolytic potential was also seen upon inspection of the secretome analysis. ROTS analysis revealed at least seven degradative proteins were present in the biofilm secretomes at significantly higher observed abundance relative to planktonic secretomes. There was a 5-fold increase in elastase abundance in biofilm secretomes, with an average quantitative protein value (QPV) of 122, compared to an average QPV of 23 in planktonic secretomes, which agreed with the results obtained from elastase enzyme activity measurements. There was a 3-fold increase in the M66 - family metalloprotease AHML_05230 in biofilm secretomes, with average QPVs of 103 and 30 in biofilm and planktonic secretomes, respectively. Both elastase and the M66 zinc metalloprotease are considered significant virulence factors of $A$. hydrophila as well as other pathogens, such as Vibrio cholerae, and enterohemorrhagic Escherichia coli $[47,48]$. Five other proteolytic enzymes were secreted in statistically significant quantities in biofilm secretomes but were not detected in the planktonic secretomes and likely increase the overall proteolytic potential of biofilm ECPs (Table 1).

While the majority of the differentially secreted degradative enzymes present in the biofilm secretome were proteolytic, two important glycolytic proteins, chitinase and chitin binding protein (CBP) were found in significantly higher amounts in biofilm secretomes. While chitinase and CBP are integral in the breakdown of environmental chitin, these proteins may also play integral roles in virulence. Though vAh can use chitin as a sole carbon source [49], the lack of chitin in the TSB growth medium would make it unlikely that chitinase and CBP production would be energetically favorable. Therefore, it is hypothesized that these chitin-associated proteins play other roles in vAh fitness or pathogenicity. In other pathogens, chitinases and CBPs are considered virulence factors not because they target chitin but because of their interactions with substrates other than chitin. In some virulent $E$. coli and $V$. cholerae, chitinases and CBPs target host glycoproteins and glycolipids that contain $\mathrm{N}$-acetylglucosamine (GlcNAc), the monomer present in mucus [50, 51]. Outer membraneexpressed chitinases and CBPs have also been indicated as accessory molecules responsible for initiating host cell adhesion and invasion [50-52]. In a murine model, $E$. coli chitin-binding domain interacts with intestinal epithelial cells, increasing invasiveness and pathogenicity [51]. In V. cholerae, Bhowmick et al. (2008) found chitinases function to break down the GlcNAc of mucin and reported upregulation of chitinases resulting from exposure to exogenous mucin. Furthermore, the $V$. cholerae chitin binding protein GbpA was shown to bind to the protective mucus layer of mammalian intestinal epithelium, resulting in bacterial colonization and disease initiation. Likewise, chitinases and CBPs produced by clinical Pseudomonas aeruginosa strains isolated from patients with cystic fibrosis (CF) were also upregulated in response to mucin-containing sputum and likely play an integral role in primary adhesion to lung epithelium in the initiation of CF [50]. In fish, the mucosal barrier covering the gills, skin, and intestinal surfaces are considered the first line of defense against invading pathogens $[53,54]$. The presence of chitinases and CBP may act to degrade not only the catfish slime coat, but also to bind to and degrade the epithelial mucins in the digestive tract, increasing vAh invasiveness. Peatman et al. (2018) reported a direct link between feed consumption and vAh-induced MAS, with survival in vAh-challenged catfish decreasing significantly when fish were fed to satiation $4 \mathrm{~h}$ prior to challenge. The mucus coating of the intestinal epithelium may decrease after eating, as ingesta moves through the digestive tract and takes mucus with it. Chitinases and CBPs may then be capable of breaking down the remaining mucus, gaining access to the underlying epithelium and, eventually, the bloodstream [55]. The presence of chitinase and CBP could help explain the intestinal epithelial damage found on necropsy in fish naturally infected with vMAS [56]. Although significantly higher in biofilm secretomes, chitinase and CBP was prominent in both planktonic and biofilm secretomes, suggesting they play an important role in bacterial fitness regardless of growth condition.

Whereas biofilm secretomes were flush with degradative exoenzymes, such as elastase, chitinases, and multiple Zn-dependent and metalloproteases, planktonic secretomes consistently produced more hemolytic and cytotoxic ECPs. Notably, both aerolysin-type and ahh1type hemolysins were detected in much higher quantities in planktonic secretomes, as were two extracellular serine proteases (neither of which were identified in any biofilm sample) and extracellular lipases, all of which exert hemolytic activity against erythrocytes, and have been shown to be cytotoxic to cells [20, 57]. Interestingly, the alpha-hemolysin, phospholipid-cholesterol acyltransferase, which was present in planktonic secretomes but absent in biofilm, has been reported to produce significant lysis of salmon erythrocytes following activation by serine protease [58]. The presence of substantial amounts of both proteins in the planktonic 
secretomes suggests that the production of these proteins could allow a multi-pronged approach to cell death, with each toxin acting independently, but increasing the collective virulence resulting from multiple exoproteins. Aerolysin-type hemolysin has been implicated as the main virulence factor of $A$. hydrophila [20], and was significantly higher in planktonic secretomes, with a three-fold increase compared to biofilm. However, ahh1type hemolysin was present in planktonic secretomes at greater than three times the amount of aerolysin-type hemolysin. Ahh1 hemolysins are homologous to hlyA hemolysins of $V$. cholerae [59]. The activity of this poreforming hemolysin is not erythrocyte-specific, but targets erythrocytes, leukocytes, lymphocytes, and epithelial and endothelial cells in a multitude of eukaryotes [60] and, as such, are considered cytotoxins. This supports the in vitro hemolysis assay results that found $80 \%$ hemolysis of channel catfish erythrocytes in one hour when exposed to planktonic supernatants, compared to less than $15 \%$ average hemolysis of erythrocytes that were incubated with biofilm supernatants (Fig. 3). The presence of these hemolysins and other cytotoxins in planktonically-cultured vAh may also help explain the rapid mortality seen in catfish when challenged by intraperitoneal injection, as these bacteria may be primed to produce vast amounts of toxins in vivo.

Biological functions of secreted proteins as analyzed by gene ontology found carbohydrate utilization to be the dominant function of secreted proteins under both conditions. Proteins involved in hemolysis, lipid and nucleotide catabolism, arginine biosynthesis, protein folding and transport were dominant biological functions of planktonic secretomes. Significant biofilm proteins were largely involved in transmembrane transport, amino acid processing, and transport of ions, amino acids, and carbohydrates. Interestingly, flagellar motility was also important in biofilms. This is likely due to A. hydrophila's use of flagella in biofilm construction and not for bacterial motility [38]. This increase in polar flagella may also contribute to an increased host colonization in biofilmassociated vAh. While lateral flagella are often considered imperative for biofilm production and adhesion [33, 61], Aeromonads that lack lateral flagella are capable of using polar flagella for biofilm formation as well as cellular adhesion [34, 38, 62, 63]. The increased polar flagella required for biofilm formation could act secondarily as adhesins when biofilm-derived bacteria come into contact with catfish mucosal surfaces and could act in concert with other secreted invasins to colonize and destroy host mucosal barriers.

\section{Conclusions}

Most aquatic bacterial generalists, such as $A$, hydrophila, spend the majority of time resident in biofilms and host- microbe interactions are likely influenced by nichespecific microbial phenotype. Because biofilm-associated bacteria have emergent properties that cannot be elucidated by the study of free-living cells, it is imperative to study organisms within biofilms to understand how niche adaptations may influence overall pathogenicity and virulence. This study is the first comparison of the secreted proteomes of vAh when grown in two distinct ecological niches. These data on the adaptive physiological response of vAh based on growth condition increase our understanding of how environmental niche partitioning could affect vAh pathogenicity and virulence. Increased secretion of colonization factors and degradative enzymes during biofilm growth and residency may increase bacterial attachment and host invasiveness, while increased secretion of hemolysins, porins, and other potential toxins under planktonic growth (or after host invasion) could result in increased host mortality. These shifts in protein expression and secretion indicate that growth under biofilm and planktonic conditions results in massive changes in gene expression. Future research should explore the global regulatory factors that affect vAh gene expression under these growth conditions. Taken together, these data may help in our understanding of the unique aspects of this emerging pathogen that contribute to the devastating impact of MAS disease outbreaks.

\section{Methods and materials Bacterial strain}

vAh strain ML09-119 was isolated from a diseased channel catfish from a MAS outbreak in a West Alabama aquaculture facility in 2009. Molecular characterization and genome sequencing of vAh ML09119 have been performed [19] and the complete genome sequence deposited in GenBank (Accession CP005966). Aliquots of vAh ML09-119 were cryogenically stored in $10 \%$ glycerol freeze medium at $-80^{\circ} \mathrm{C}$.

\section{Catfish}

Specific-pathogen free channel catfish fingerlings maintained under Auburn University IACUC-approved protocol 2018-3251 (Catfish Production and Maintenance) were used for challenges. All challenges were performed adhering to the guidelines of AU-IACUCapproved protocol 2016-2900 (Identification of toxigenic proteins of virulent Aeromonas hydrophila and evaluation of host response).

\section{Culture media and culture conditions}

Tryptic soy broth (TSB) (Bacto TSB, BD) prepared according to manufacturer's directions was used as the culture medium for planktonic growth. 
Biofilm media was prepared by adding $0.2 \%$ agar powder (AlfaAesar) to TSB media prior to sterilization, and $70 \mathrm{ml}$ of molten agar was poured into deep well petri dishes (Fisher), as previously described [64].. An aliquot of vAh ML09-119 was removed from cryogenic storage and cultured in TSB overnight at $30^{\circ} \mathrm{C}$ on an orbital shaker. This culture was then used to prepare planktonic and biofilm cultures, as previously described [64]. Briefly, $70 \mathrm{ml}$ of fresh TSB media was inoculated with $1 \mathrm{ml}$ of the overnight culture and grown at $30^{\circ} \mathrm{C}$ with shaking to mid-log phase. Biofilm agar plates were inoculated from overnight culture by stab inoculation, sealed with parafilm, and incubated at $30{ }^{\circ} \mathrm{C}$ for $72 \mathrm{~h}$. Planktonic and biofilm cultures were performed in triplicate.

\section{Secretome preparation} Planktonic Secretome

Secreted proteins of planktonically-cultured vAh ML09119 were purified from cell-free supernatants, prepared as previously described [64]. Briefly, vAh was cultured in TSB media as described above, cells were pelleted by centrifugation, and supernatant was decanted and retained. Pelleted cells were washed twice with cold, sterile PBS, pelleted as above, and the wash was added to the supernatant. Combined supernatants were then passed through a low-binding $0.22 \mu \mathrm{m}$ vacuum filter (VWR) to remove any remaining cells.

\section{Biofilm Secretome}

Secreted proteins of biofilm-cultured vAh ML09-119 were purified from cell-free supernatants, as previously described [64]. In brief, cells were removed from the biofilm media surface and washed twice with cold, sterile PBS as described above. The cell wash was decanted and retained. Secreted proteins were then collected from within the biofilm media by disrupting the biofilm media until the soft agar had formed a slurry. The slurry was transferred to conical tubes, centrifuged to pellet the agar, and the liquid media was decanted and retained. The agar plug was then resuspended in sterile PBS and centrifuged as above. The wash solutions was decanted and retained. All retained supernatants were combined and residual agar and bacterial cells were removed by filtration through a low-binding $0.45 \mu \mathrm{m}$ and $0.22 \mu \mathrm{m}$ vacuum filters (VWR).

\section{Ammonium sulfate precipitation}

Extracellular proteins (ECPs) were precipitated from cell-free supernatants by ammonium sulfate precipitation, as previously described [30, 64]. Briefly, ammonium sulfate crystals (Fisher Scientific) were added to cell-free supernatants to achieve $65 \%$ saturation and incubated at $4{ }^{\circ} \mathrm{C}$ with gentle mixing for $24 \mathrm{~h}$. Precipitated proteins were collected by centrifugation, resuspended in Tris buffer, and dialyzed twice against the same buffer in 10 Kda dialysis cassettes (Slide-A-Lyzer (Thermo Fisher)). Following dialysis, the volume of all protein samples were adjusted to $20 \mathrm{ml}$ by the addition of cold Tris buffer. Protein concentration of each sample was determined by the Bradford assay (Pierce Coomassie Plus Protein Assay, Thermo Fisher). These concentrated proteins were used for all enzymatic assays.

\section{Enzymatic activity}

The in vitro activity of secreted proteins was measured using specific substrates to determine the degradative and toxigenic potential of planktonic and biofilm secretomes, as described below:

\section{Hemolysis}

Hemolytic potential was measured using the method of Barger et al. (2020). In brief, heparinized blood from channel catfish was diluted 1:10 in sterile PBS and incubated with a suitable dilutions of protein for $2 \mathrm{~h}$ at $30^{\circ} \mathrm{C}$ in an orbital shaker. Positive control tubes representing $100 \%$ hemolysis contained sterile distilled water in place of protein samples. Negative control tubes contained sterile PBS in place of protein samples. Following incubation, tubes were centrifuged to pellet un-lysed erythrocytes and supernatant was transferred to clear, 96-well flat bottom plates. Hemolysis was quantified by measuring absorbance of released hemoglobin at $415 \mathrm{~nm}$ in multi-mode plate reader (Synergy HTX, Bio-Tek) and hemolysis was reported as percent of positive control.

\section{Universal protease activity}

Non-specific proteolytic activity was measured using HiLyteFluor 488-labeled casein as the substrate, following manufacturer's protocol with minor modifications (Sensolyte Green Fluorimetric Protease Assay Kit, AnaSpec, Inc.), as previously described [64]. Briefly, a suitable concentration of protein was added to triplicate wells of black, flat-bottom 96-well plates with nonbinding surface (Greiner Bio-One). Trypsin served as a positive control and sterile deionized water served as a substrate control. Labeled casein was added to each well and relative fluorescence was measured at $\mathrm{Ex} / \mathrm{Em}=490$ $\mathrm{nm} / 520 \mathrm{~nm}$ every five minutes for one hour in a multimode plate reader (Synergy HTX, Bio-Tek) with $30^{\circ} \mathrm{C}$ incubation temperature. Data were plotted as relative fluorescence units versus time for each sample.

\section{Elastase activity}

Elastase-specific activity was measured using 5-FAM/ QXL $^{\mathrm{rm}} 520$ labelled elastin as the substrate, following the manufacturer's protocol with minor modifications (Sensolyte Green Fluorimetric Elastase Assay Kit, AnaSpec, Inc.), as previously described [64]. Briefly, a suitable 
concentration of protein was added to triplicate wells of black, flat-bottom 96-well plates with non-binding surface. Positive and negative controls were elastase and sterile, deionized water, respectively. Labeled elastin substrate was then added to each well and relative fluorescence was measured continuously at $\mathrm{Ex} / \mathrm{Em}=490 \mathrm{~nm} /$ $520 \mathrm{~nm}$ for one hour in a multi-mode plate reader (Synergy HTX, Bio-Tek) with $30^{\circ} \mathrm{C}$ incubation temperature. Data were plotted as relative fluorescence units versus time for each sample.

\section{In vivo proteolysis}

Extracellular protein activity was measured in vivo using channel catfish fingerlings to determine potential proteolytic and cytotoxic tissue effects.

\section{Protein preparation}

Ten microgram aliquots of secreted planktonic and biofilm-associated proteins, prepared as above, diluted in $100 \mu \mathrm{l}$ sterile PBS were used for injection challenges.

\section{Challenge model}

Channel catfish fingerlings were transferred to 57-1 glass aquaria containing dechlorinated municipal water and acclimated at $30^{\circ} \mathrm{C}$ for two days prior to challenge. Triplicate tanks containing five fish each represented planktonic ECP, biofilm-associated ECP, and injection control groups. Prior to injection, fingerlings were transferred to sedation aquaria containing $70 \mathrm{mg} / \mathrm{L}$ tricaine methanesulfonate (MS-222) buffered to neutrality with sodium bicarbonate. Following sedation, characterized by decreased opercular movement and loss of equilibrium, $100 \mu \mathrm{l}$ of sterile PBS containing $10 \mu \mathrm{g}$ of total protein was injected intramuscularly just below the dorsal fin using tuberculin syringes fitted with 26 gauge needles. Control fish were injected with $100 \mu$ sterile PBS. Fish were then returned to the appropriate aquarium and monitored until fully recovered. Fish were maintained in aquaria at $30^{\circ} \mathrm{C}$ for 7 days under flow-through conditions at 1 gal per hour water replacement. Moribund fish or fish developing severe external lesions were euthanized by prolonged exposure to buffered MS-222, the tissues were collected and fixed in 10\% neutral-buffered formalin. After 7 days, remaining fish were humanely euthanized and samples were collected and prepared as above.

\section{Histology}

Formalin-fixed tissues were paraffin-embedded and $4 \mu \mathrm{m}$ sections were prepared and stained with hematoxylin and eosin according to standard methods [65]. Slides were evaluated and photographed using an Olympus BX53 microscope with an Olympus UPlanFL N 20X/ 0.50 objective, fitted with an Olympus DP26 digital camera, and captured with Olympus cellSens Entry Imagining software (Olympus Corporation). No further imaging processing or manipulation was performed on photomicrographs.

\section{Secretome analysis}

To determine how vAh niche occupancy might influence protein production, secreted protein profiles of vAh cultured within a biofilm and in broth were compared by liquid chromatography with tandem mass spectrometry (LC MS/MS) analysis at the University of Alabama at Birmingham Mass Spectrometry/Proteomics shared facility (Birmingham, Alabama, USA) to identify and quantify proteins present in each sample, as previously described [30], as follows.

\section{Proteomics analysis}

Samples were prepared for analysis as follows: $20 \mu \mathrm{g}$ of protein per sample in NuPAGE LDS sample buffer (Invitrogen) was loaded onto a Novex NuPage 10\% Bis-Tris protein gel (Invitrogen), separated as a short stack, and stained overnight with Novex Colloidal Blue Staining kit (Invitrogen). Gels were then destained and lanes were cut into single molecular weight fractions. Following equilibration in $100 \mathrm{mM}$ ammonium bicarbonate, fractions were digested overnight with Trypsin Gold (Mass Spectrometry grade (Promega)) and peptide extracts were reconstituted in $0.1 \%$ formic acid to $0.1 \mu \mathrm{g} / \mu \mathrm{l}$.

\section{Mass spectrometry}

Digested samples were analyzed on a 260 Infinity HPLC stack (Agilent Technologies) and chromatographic separation occurred on a C18 reverse-phase column (Jupiter C-18, $71 \mu \times 15 \mathrm{~cm}, 300 \AA, 5 \mu \mathrm{m}$ (Phenomenex)) with an in-line Thermo Orbitrap Velos Pro hybrid mass spectrometer, equipped with a nano-electrospray source (Thermo Fisher). Binary mobile phase solvents were comprised of $0.1 \%$ formic acid (solvent A) and $0.1 \%$ formic acid in $85 \%$ acetonitrile (solvent B). All data were collected in CID mode. A parent scan range of 300 to $1200 \mathrm{~m} / \mathrm{z}$ (at $60 \mathrm{~K}$ resolution) was chosen and fragmentation data (MS2) were collected on the top 15 most intense ions. For data-dependent acquisition, charge-state screening and dynamic exclusion were enabled with a repeat count of 2, repeat duration of 30s, and exclusion duration of $90 \mathrm{~s}$.

\section{Mass spectrometry data conversion and searches}

Data acquisition was executed using Xcalibur software. Xcalibur RAW files were collected in profile mode, converted to centroid data, and then converted to mzXML using ReAdW v3.5.1 (IonSource). The mgf files were then created using MzXML2Search (included in TransProteomics Pipeline v3.5) for all scans. The data were 
searched with a species-specific subset of the UniRef 100 database using SEQUEST (Thermo Fisher, San Jose, CA, USA; version 27), which was set for two maximum missed cleavages, a precursor mass window of $20 \mathrm{ppm}$, trypsin digestion, variable modification $\mathrm{C}$ at 57.0293, and $\mathrm{M}$ at 15.9949 .

\section{Peptide filtering, grouping, quantification and statistical analyses}

Scaffold (v. 4.8.4, Proteome Software Inc., Portland, Oregon) was used to validate MS/MS based peptide and protein identifications. Peptides identified by SEQUEST search were filtered with Scaffold. A minimum peptide length of $>5$ amino acids, with no $\mathrm{MH}+$ charge states, peptide probabilities of $>80 \%$ C.I., and with the number of unique peptides per protein $\geq 2$ were set as filter cutoff values required to accept peptide identification. Peptide probabilities were assigned by the PeptideProphet algorithm [66, 67]. The two most common methods for statistical validation of large proteome data, False discovery rate (FDR) and protein probability, are incorporated in Scaffold. Protein identifications were accepted if proteins probabilities could be established at $>99 \%$ C.I., contained at least 4 identified peptides, and with false discovery rate $<1.0$. Spectral counting and was performed for relative quantification across samples. Spectral count abundances were normalized between samples, when relevant. Proteins present in at least two experimental replicates were included in analyses. To identify differentially secreted proteins, two nonparametric statistical analyses including reproducibilityoptimized test statistic (ROTS) (bootstrapping value = $1000)$ combined with single-tail t-test $(p<0.05)[68,69]$ were performed between each pair-wise comparison. These were then sorted according to the highest statistical relevance in each comparison. For protein abundance ratios determined by normalized spectral counts, a fold change threshold $\geq 1.5$ was set for significance. For proteins present in only one experimental group, the average of the normalized quantitative value was designated as the protein abundance.

\section{Protein function}

To define the potential function of secreted proteins, major biological processes of statistically significant proteins were determined from gene ontology annotation in UniProt (Consortium, T.U. 2018) and QuickGO [70]. Predicted protein function was assessed by determining major biological processes through gene ontology. Using these data, eight functional groups were established, and proteins were sorted into these groups based on their primary biological function. A further comparison was made by compiling all proteins in each functional group from both biofilm and planktonic secretomes and expressing as parts of a whole, with side-by-side comparisons for each secretome type.

\section{Statistical analyses}

Reproducibility-optimized test statistic (ROTS) analysis of differentially secreted proteins was performed in $\mathrm{R}$ [71]. All other statistical analyses were performed in Prism 8.2.0 (Graphpad). One-way ANOVA followed by Tukey's multiple comparisons post-test were performed on triplicate data with significance set at $p<0.05$. Graphical representations of data were produced in Prism 8.2.0.

\section{Supplementary Information}

The online version contains supplementary material available at https://doi. org/10.1186/s12866-020-02065-2

\section{Additional file 1}

Additional file 2 .

\section{Acknowledgements}

The authors wish to thank the team at the Mass Spectrometry/Proteomics Shared Facility at the University of Alabama at Birmingham School of Medicine for HPLC-MS/MS analyses. The authors also thank the Auburn University College of Veterinary Medicine, Department of Pathobiology for research support and the USDA Agricultural Research Service (Auburn, Alabama) for invaluable collaborative efforts.

\section{Authors' contributions}

$\mathrm{PB}, \mathrm{ML}$, and JN conceived and designed experiments. PB performed protein isolation, screening, and analyses of proteomics. JN and PB performed in vivo challenges. JN performed histopathology analyses and imaging. $\mathrm{ML}$ and $\mathrm{JN}$ provided expert guidance on analyses of proteomics and fish disease pathology, respectively. BB provided proteomics instrumentation support and critical review. All authors contributed to and approved the preparation and review of the manuscript.

\section{Funding}

Research funding was provided by competitive grants from the Auburn University College of Veterinary Medicine's Animal Health and Disease Research Program. Funding for publication was provided by the Department of Pathobiology at the Auburn University College of Veterinary Medicine.

\section{Availability of data and materials}

Data generated or analyzed during the current study are included in this published article and its supplementary information file.

Ethics approval and consent to participate

Not applicable.

Consent for publication

Not applicable.

\section{Competing interests}

The authors declare they have no competing interests.

\section{Author details}

'Department of Pathobiology, College of Veterinary Medicine, Auburn University, Auburn, AL, USA. ${ }^{2}$ Biological Sciences, College of Sciences and Math, Auburn University, Auburn, AL, USA. ${ }^{3}$ USDA ARS Aquatic Animal Health Research Unit, Auburn, AL, USA. 
Received: 31 August 2020 Accepted: 7 December 2020 Published online: 06 January 2021

\section{References}

1. Janda JM, Abbott SL. The genus Aeromonas: taxonomy, pathogenicity, and infection. Clin Microbiol Rev. 2010;23:35-73.

2. Peatman E, Mohammed H, Kirby A, Shoemaker CA, Yildirim-Aksoy M, Beck $\mathrm{BH}$. Mechanisms of pathogen virulence and host susceptibility in virulent Aeromonas hydrophila infections of channel catfish (Ictalurus punctatus). Aquaculture. 2018;482:1-8.

3. Jaccard N, Griffin LD, Keser A, Macown RJ, Super A, Veraitch FS, Szita N Automated method for the rapid and precise estimation of adherent cell culture characteristics from phase contrast microscopy images. Biotechnol Bioeng. 2014;111:504-17.

4. Seshadri R, Joseph SW, Chopra AK, Sha J, Shaw J, Graf J, Haft D, Wu M, Ren Q, Rosovitz MJ, Madupu R, Tallon L, Kim M, Jin S, Vuong H, Stine OC, Ali A, Horneman AJ, Heidelberg JF. Genome sequence of Aeromonas hydrophila ATCC 7966T: jack of all trades. J Bacteriol. 2006;188:8272-82.

5. Holmes P, Niccolls LM, Sartory DP. The ecology of mesophilic Aeromonas in the aquatic environment. In: Austin B, Altwegg M, Gosling PJ, Joseph S, editors. The genus Aeromonas. New York: J. Wiley; 1996. p. 127-50.

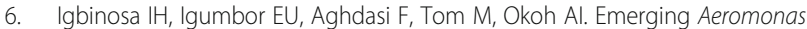
species infections and their significance in public health. Sci World J. 2012; 2012:625023.

7. Grim CJ, Kozlova EV, Ponnusamy D, Fitts EC, Sha J, Kirtley ML, van Lier CJ, Tiner BL, Erova TE, Joseph SJ, Read TD, Shak JR, Joseph SW, Singletary E, Felland T, Baze WB, Horneman AJ, Chopra AK. Functional genomic characterization of virulence factors from necrotizing fasciitis-causing strains of Aeromonas hydrophila. Appl Environ Microbiol. 2014;80:4162-83.

8. Gosling PJ. Aeromonas species in disease of animals. In: Austin B, Altwegg M, Gosling PJ, Joseph S, editors. The Genus Aeromonas. New york: J. Wiley; 1996. p. 175-95.

9. Igbinosa IH, Okoh Al. Antibiotic susceptibility profile of Aeromonas species isolated from wastewater treatment plant. Sci World J. 2012;2012:764563.

10. Beaz-Hidalgo R, Figueras MJ. Aeromonas spp. whole genomes and virulence factors implicated in fish disease. J Fish Dis. 2013;36:371-88

11. Griffin MJ, Goodwin AE, Merry GE, Liles MR, Williams MA, Ware C, Waldbieser GC. Rapid quantitative detection of Aeromonas hydrophila strains associated with disease outbreaks in catfish aquaculture. J Vet Diagn Investig. 2013;25: 473-81.

12. Austin B, Adams C. Fish pathogens. In: Austin B, Altwegg M, Gosling PJ, Joseph S, editors. The genus Aeromonas. New York: J. Wiley; 1996.

13. Camus AC, Durborow WG, Hemstreet WB, Thune RL, Hawke JP. Aeromonas bacterial infections - motile aeromonad septicemia. Southern Regional Aquaculture Center Publication. 1998;478:4.

14. Cipriano RC. In: United States Department of the Interior FaWSDoFR, editor. Aeromonas hydrophila and motile aeromonad septicemia of fish. Washington, D.C; 2001

15. Hossain MJ, Sun D, McGarey DJ, Wrenn S, Alexander LM, Martino ME, Xing Y, Terhune JS, Liles MR. An Asian origin of virulent Aeromonas hydrophila responsible for disease epidemics in United States-farmed catfish. MBio. 2014:5:e00848-14.

16. Hossain MJ, Waldbieser GC, Sun D, Capps NK, Hemstreet WB, Carlisle K, Griffin MJ, Khoo L, Goodwin AE, Sonstegard TS, Schroeder S, Hayden K, Newton JC, Terhune JS, Liles MR. Implication of lateral genetic transfer in the emergence of Aeromonas hydrophila isolates of epidemic outbreaks in channel catfish. PLoS One. 2013;8:e80943.

17. Pridgeon JW, Klesius PH. Molecular identification and virulence of three Aeromonas hydrophila isolates cultured from infected channel catfish during a disease outbreak in West Alabama (USA) in 2009. Dis Aquat Org. 2011;94: 249-53.

18. Pridgeon JW, Klesius PH, Song L, Zhang D, Kojima K, Mobley JA. Identification, virulence, and mass spectrometry of toxic ECP fractions of West Alabama isolates of Aeromonas hydrophila obtained from a 2010 disease outbreak. Vet Microbiol. 2013;164:336-43.

19. Tekedar HC, Waldbieser GC, Karsi A, Liles MR, Griffin MJ, Vamenta S, Sonstegard T, Hossain M, Schroeder SG, Khoo L, Lawrence ML. Complete genome sequence of a channel catfish epidemic isolate, Aeromonas hydrophila Strain ML09-119. Genome Announc. 2013;1(5):e00755-13.https:// doi.org/10.1128/genomeA.00755-13.
20. Tomas JM. The main Aeromonas pathogenic factors. ISRN Microbiol. 2012; 2012:256261.

21. Rasmussen-Ivey CR, Figueras MJ, McGarey D, Liles MR. Virulence factors of Aeromonas hydrophila: in the wake of reclassification. Front Microbiol. 2016; 7:1337.

22. Citterio B, Francesca B. Aeromonas hydrophila virulence. Virulence. 2015;6: 417-8.

23. Abdelhamed H, Ibrahim I, Nho SW, Banes MM, Wills RW, Karsi A, Lawrence ML. Evaluation of three recombinant outer membrane proteins, OmpA1, $T d r$, and TbpA, as potential vaccine antigens against virulent Aeromonas hydrophila infection in channel catfish (Ictalurus punctatus). Fish Shellfish Immunol. 2017:66:480-6.

24. Bales PM, Renke EM, May SL, Shen Y, Nelson DC. Purification and characterization of biofilm-associated EPS exopolysaccharides from ESKAPE organisms and other pathogens. PLoS One. 2013:8:e67950.

25. Costerton JW, Cheng KJ, Geesey GG, Ladd TI, Nickel JC, Dasgupta M, Marrie TJ. Bacterial biofilms in nature and disease. Annu Rev Microbiol. 1987;41: 435-64.

26. Hall-Stoodley L, Costerton JW, Stoodley P. Bacterial biofilms: from the natural environment to infectious diseases. Nat Rev Microbiol. 2004;2:95108.

27. Jefferson KK. What drives bacteria to produce a biofilm? FEMS Microbiol Lett. 2004;236:163-73.

28. Johnson TL, Fong JC, Rule C, Rogers A, Yildiz FH, Sandkvist M. The type II secretion system delivers matrix proteins for biofilm formation by Vibrio cholerae. J Bacteriol. 2014;196:4245-52.

29. Weinbauer MG, Hofle MG. Distribution and life strategies of two bacterial populations in a eutrophic lake. Appl Environ Microbiol. 1998;64:3776-83.

30. Thurlow CM, Hossain MJ, Sun D, Barger P, Foshee L, Beck BH, Newton JC, Terhune JS, Saper MA, Liles MR. The gfc operon is involved in the formation of the $\mathrm{O}$ antigen capsule in Aeromonas hydrophila and contributes to virulence in channel catfish. Aquaculture. 2019;512:734334.

31. Wang Y, Wang X, Ali F, Li Z, Fu Y, Yang X, Lin W, Lin X. Comparative Extracellular Proteomics of Aeromonas hydrophila Reveals Iron-Regulated Secreted Proteins as Potential Vaccine Candidates. Front Immunol. 2019;10: 256.

32. Bjarnsholt T, Alhede M, Alhede M, Eickhardt-Sorensen SR, Moser C, Kuhl M, Jensen PO, Hoiby N. The in vivo biofilm. Trends Microbiol. 2013;21:466-74.

33. Gavin R, Rabaan AA, Merino S, Tomas JM, Gryllos I, Shaw JG. Lateral flagella of Aeromonas species are essential for epithelial cell adherence and biofilm formation. Mol Microbiol. 2002;43:383-97.

34. Lowry R, Balboa S, Parker JL, Shaw JG. Aeromonas flagella and colonisation mechanisms. Adv Microb Physiol. 2014;65:203-56.

35. Redfield RJ. Is quorum sensing a side effect of diffusion sensing? Trends Microbiol. 2002;10:365-70.

36. Khajanchi BK, Sha J, Kozlova EV, Erova TE, Suarez G, Sierra JC, Popov VL, Horneman AJ, Chopra AK. N-acylhomoserine lactones involved in quorum sensing control the type $\mathrm{VI}$ secretion system, biofilm formation, protease production, and in vivo virulence in a clinical isolate of Aeromonas hydrophila. Microbiology. 2009;155:3518-31.

37. De Schryver $\mathrm{P}$, Vadstein O. Ecological theory as a foundation to control pathogenic invasion in aquaculture. ISME J. 2014;8:2360-8.

38. Canals R, Ramirez S, Vilches S, Horsburgh G, Shaw JG, Tomás JM, Merino S. Polar flagellum biogenesis in Aeromonas hydrophila. J Bacteriol. 2006;188:542.

39. Dacanay A, Boyd JM, Fast MD, Knickle LC, Reith ME. Aeromonas salmonicida type I pilus system contributes to host colonization but not invasion. Dis Aquat Org. 2010;88:199-206.

40. Zhang D, Xu D-H, Shoemaker C. Experimental induction of motile Aeromonas septicemia in channel catfish (Ictalurus punctatus) by waterborne challenge with virulent Aeromonas hydrophila. Aquacult Rep. 2016:3:18-23.

41. Davey ME, O'toole GA. Microbial biofilms: from ecology to molecular genetics. Microbiol Mol Biol Rev. 2000;64:847-67.

42. Stewart PS, Franklin MJ. Physiological heterogeneity in biofilms. Nat Rev Microbiol. 2008;6:199-210.

43. Reid G. Biofilms in infectious disease and on medical devices. Imt J Antimicrob Agents. 1999;11:223-6.

44. Brown SP, Cornforth DM, Mideo N. Evolution of virulence in opportunistic pathogens: generalism, plasticity, and control. Trends Microbiol. 2012;20: $336-42$. 
45. Cai W, Willmon E, Burgos FA, Ray CL, Hanson T, Arias CR. Biofilm and sediment are major reservoirs of virulent Aeromonas hydrophila (vAh) in catfish production ponds. J Aquat Anim Health. 2019;31(1):112-20. https:// doi.org/10.1002/aah.10056.

46. Pang M, Jiang J, Xie X, Wu Y, Dong Y, Kwok AH, Zhang W, Yao H, Lu C, Leung FC, Liu Y. Novel insights into the pathogenicity of epidemic Aeromonas hydrophila ST251 clones from comparative genomics. Sci Rep. 2015:5:9833.

47. Yu Angel CY, Worrall Liam J, Strynadka Natalie CJ. Structural insight into the bacterial Mucinase StcE essential to adhesion and immune evasion during Enterohemorrhagic E. coli infection. Structure. 2012;20:707-17.

48. Russell W, Herwald H. Concepts. In: Schmidt A, Herwald H, editors. Bacterial Virulence. Basel, Switzerland: Karger; 2005.

49. Zhang D, Xu DH, Qiu J, Rasmussen-Ivey CR, Liles MR, Beck BH. Chitin degradation and utilization by virulent Aeromonas hydrophila strain ML1051K. Arch Microbiol. 2017;199:573-9.

50. Tran HT, Barnich N, Mizoguchi E. Potential role of chitinases and chitinbinding proteins in host-microbial interactions during the development of intestinal inflammation. Histol Histopathol. 2011;26:1453-64.

51. Low D, Tran HT, Lee IA, Dreux N, Kamba A, Reinecker HC, DarfeuilleMichaud A, Barnich N, Mizoguchi E. Chitin-binding domains of Escherichia coli ChiA mediate interactions with intestinal epithelial cells in mice with colitis. Gastroenterology. 2013;145:602-12 e9.

52. Bhowmick R, Ghosal A, Das B, Koley H, Saha DR, Ganguly S, Nandy RK, Bhadra RK, Chatterjee NS. Intestinal adherence of Vibrio cholerae involves a coordinated interaction between colonization factor GbpA and Mucin Infect Immun. 2008;76:4968.

53. Peatman $E$, Lange $M$, Zhao H, Beck BH. Physiology and immunology of mucosal barriers in catfish (Ictalurus spp.). Tissue Barriers. 2015;3:e1068907.

54. Dash S, Das SK, Samal J, Thatoi HN. Epidermal mucus, a major determinant in fish health: a review. Iran J Vet Res. 2018;19:72-81.

55. Johansson ME, Sjovall H, Hansson GC. The gastrointestinal mucus system in health and disease. Nat Rev Gastroenterol Hepatol. 2013;10:352-61.

56. Baumgartner WA, Ford L, Hanson L. Lesions caused by virulent Aeromonas hydrophila in farmed catfish (Ictalurus punctatus and I. punctatus $\times 1$. furcatus) in Mississippi. Journ Vet Diagn Invest. 2017;29:747-51.

57. Vences A, Rivas AJ, Lemos ML, Husmann M, Osorio CR. Chromosomeencoded Hemolysin, phospholipase, and collagenase in Plasmidless isolates of Photobacterium damselae subsp. damselae contribute to virulence for fish. Appl Environ Microbiol. 2017;83:e00401-17.

58. Eggset G, BjØRnsdottir R, Leifson RM, Arnesen JA, Coucheron DH, JØRgensen $T \varnothing$. Extracellular glycerophospholipid:cholesterol acyltransferase from Aeromonas salmonicida: activation by serine protease. J Fish Dis. 1994; 17:17-29.

59. Heuzenroeder MW, Wong CY, Flower RL. Distribution of two hemolytic toxin genes in clinical and environmental isolates of Aeromonas spp.: correlation with virulence in a suckling mouse model. FEMS Microbiol Lett. 1999;174:131-6.

60. Chenal A, Sotomayor-Perez AC, Ladant D. 23 - structure and function of RTX toxins. In: Alouf J, Ladant D, Popoff MR, editors. The comprehensive sourcebook of bacterial protein toxins (Fourth Edition). Boston: Academic Press; 2015. p. 677-718.

61. Gavin R, Merino S, Altarriba M, Canals R, Shaw JG, Tomas JM. Lateral flagella are required for increased cell adherence, invasion and biofilm formation by Aeromonas spp. FEMS Microbiol Lett. 2003;224:77-83.

62. Kirov SM, Castrisios M, Shaw JG. Aeromonas flagella (polar and lateral) are enterocyte adhesins that contribute to biofilm formation on surfaces. Infect Immun. 2004;72:1939-45.

63. Rabaan AA, Gryllos I, Tomás JM, Shaw JG. Motility and the polar flagellum are required for Aeromonas caviae adherence to HEp-2 cells. Infect Immun. 2001;69:4257.

64. Barger PC, Liles MR, Newton JC. Type II secretion is essential for virulence of the emerging fish pathogen, hypervirulent Aeromonas hydrophila. Front Vet Sci. 2020;7:706.

65. Feldman AT, Wolfe D. Tissue processing and hematoxylin and eosin staining. Methods Mol Biol. 2014;1180:31-43.

66. Keller A, Nesvizhskii Al, Kolker E, Aebersold R. Empirical statistical model to estimate the accuracy of peptide identifications made by MS/MS and database search. Anal Chem. 2002;74:5383-92.
67. Nesvizhskii Al, Keller A, Kolker E, Aebersold R. A statistical model for identifying proteins by tandem mass spectrometry. Anal Chem. 2003;75: 4646-58.

68. Pursiheimo A, Vehmas AP, Afzal S, Suomi T, Chand T, Strauss L, Poutanen M, Rokka A, Corthals GL, Elo LL. Optimization of statistical methods impact on quantitative proteomics data. J Proteome Res. 2015;14:4118-26.

69. Suomi T, Elo LL. Enhanced differential expression statistics for dataindependent acquisition proteomics. Sci Rep. 2017;7:5869.

70. Binns D, Dimmer E, Huntley R, Barrell D, O'Donovan C, Apweiler R. QuickGO: a web-based tool for Gene Ontology searching. Bioinformatics (Oxford, England). 2009;25:3045-6.

71. R Core Team. R: A language and environment for statistical computing. Vienna, Austria. https://www.R-project.org/. R Foundation for Statistical Computing; 2017.

\section{Publisher's Note}

Springer Nature remains neutral with regard to jurisdictional claims in published maps and institutional affiliations.
Ready to submit your research? Choose BMC and benefit from:

- fast, convenient online submission

- thorough peer review by experienced researchers in your field

- rapid publication on acceptance

- support for research data, including large and complex data types

- gold Open Access which fosters wider collaboration and increased citations

- maximum visibility for your research: over $100 \mathrm{M}$ website views per year

At $\mathrm{BMC}$, research is always in progress.

Learn more biomedcentral.com/submissions 